\title{
Sosialisasi dan Praktik Aplikasi Pupuk Organik dengan Menggunakan Pesawat Tanpa Awak (Drone) pada Tanaman Padi
}

\author{
Muji Rahayu*, Edi Purwanto, Amalia Tetrani Sakya, Djoko Purnomo, Samanhudi, Ahmad Yunus, \\ Gani Cahyo Handoyo, Andriyana Setyawati, Retna Bandriyati Arniputri, Dwi Harjoko
}

Program Studi Agroteknologi, Fakultas Pertanian, Universitas Sebelas Maret, Surakarta

*Correspoding Author: mujirahayu@ staff.uns.ac.id

\begin{abstract}
ABSTRAK
Upaya peningkatan produksi padi penting dilakukan untuk mendukung ketahanan pangan nasional. Penerapan teknologi di bidang pertanian sangat penting dilakukan. Penggunaan mesin otomatis yang terintegrasi dengan internet merupakan salah satu ciri revolusi industri 4.0. Seluruh aspek, terutama petani sebagai pelaku perlu dipersiapkan untuk menuju pertanian yang berbasis revolusi industri 4.0. Kegiatan ini bertujuan memberikan pengetahuan, wawasan dan contoh kepada petani di Desa Gentan, Kecamatan Bendosari, Kabupaten Sukoharjo mengenai penggunaan pesawat tanpa awak (drone) dalam aplikasi pupuk organik sebagai upaya meningkatkan produksi padi. Kegiatan pengabdian masyarakat ini dilakukan dalam beberapa tahapan, meliputi koordinasi dan penentuan lahan, sosialisasi dan penyuluhan, praktik penyemprotan pupuk organik dengan menggunakan pesawat tanpa awak, monitoring dan evaluasi. Hasil pengabdian masyarakat ini menunjukkan bahwa petani mendapatkan wawasan berkaitan dengan revolusi industri 4.0 dalam aplikasi pupuk organik dengan menggunakan pesawat tanpa awak pada tanaman padi. Petani anggota Gapoktan Sari Tani juga sangat antusias dalam mengikuti kegiatan penyuluhan, sosialisasi dan praktik penyemprotan pupuk organik dengan menggunakan pesawat tanpa awak.
\end{abstract}

Kata kunci: padi, pupuk organik, sosialisasi, pesawat tanpa awak

\section{ABSTRACT}

Efforts to increase rice production are important to support national food security. The application of technology in agriculture is very important. The use of automatic machines that are integrated with the internet is one of the characteristics of the 4.0 industrial revolution. To get to agriculture based on industrial revolution 4.0, readiness is needed from all aspects, especially farmers as actors. This community service aims to provide knowledge, insight and instance to farmers in Gentan Village, Bendosari District, Sukoharjo Regency regarding the use of drones in organic fertilizer applications in an effort to increase rice production. This community service activity is done in several stages, including coordination and determination land, socialization and extension, organic fertilizer spraying practices using drones, monitoring and evaluation. The results of this activity show that farmers gained insight and knowledge of the industrial revolution 4.0 in organic fertilizer applications using drones. Farmers of Gapoktan Sari Tani members are also very enthusiastic in participating in extension activities, socialization and organic fertilizer spraying practices using drones.

Keywords: rice, organic fertilizer, socialization, drones

\section{PENDAHULUAN}

Kelompok Tani "Sari Tani" Desa Gentan, Kecamatan Bendosari, Kabupaten Sukoharjo merupakan kelompok tani yang Sebagian besar petaninya menanam padi. Peningkatan produksi padi merupakan upaya dalam rangka mewujudkan ketahanan pangan nasional (Hernanda et al., 2017). Salah satu sektor penting untuk mencukupi kebutuhan pangan rakyat adalah pertanian. Adapun masalah yang dihadapi adalah lahan yang luas namun tenaga terbatas, sehingga perlu adanya teknologi yang dapat membantu petani dalam kegiatan pertanian 
khususnya dalam pengendalian hama, penyakit, dan gulma. Oleh sebab itu, kegiatan di bidang pertanian sebaiknya diintegrasikan dengan teknologi yang berkembang (Fatchiya et al., 2016).

Untuk mendukung usaha pertanian, aplikasi teknologi penting dilakukan untuk mengatasi berbagai kendala yang ada. Revolusi Industri 4.0 yang dicirikan dengan aplikasi mesin otomatis yang terintegrasi dengan internet membutuhkan kesiapan dalam berbagai aspek yang terlibat, terutama petani sebagai pelaku (Kilmanun \& Astuti, 2020).

Sosialisasi dan pengenalan teknologi yang mampu mempermudah kegiatan dalam pertanian perlu dilakukan. Peralatan atau mesin yang dapat mempermudah penyemprotan, baik dalam pemupukan maupun pengendalian hama, penyakit, dan gulma merupakan salah satu peralatan yang sangat diperlukan petani. Melalui penggunaan peralatan tersebut, maka akan membantu petani dalam manajemen waktu serta tenaga yang efektif dan efisien.

Petani di Desa Gentan, Kecamatan Bendosari, Kabupaten Sukoharjo sudah terbiasa memakai pupuk organik cair pada tanaman padi, namun aplikasinya masih menggunakan sprayer sehingga membutuhkan tenaga, waktu, dan biaya yang banyak. Oleh karena itu, kegiatan pengabdian masyarakat ini perlu dilakukan untuk memberikan wawasan, dan contoh pada petani di Desa Gentan, Kecamatan Bendosari, Kabupaten Sukoharjo mengenai penggunaan pesawat tanpa awak dalam aplikasi pupuk organik sebagai upaya untuk meningkatkan produksi padi.

\section{METODE}

Pelaksanaan pengabdian masyarakat ini dilakukan dalam beberapa tahapan, meliputi koordinasi dan penentuan lahan, sosialisasi dan penyuluhan, praktik penyemprotan pupuk organik dengan menggunakan pesawat tanpa awak, monitoring serta evaluasi. Koordinasi rencana pelaksanaan kegiatan pengabdian masyarakat dilakukan oleh tim pengabdian masyarakat dengan kepala desa dan ketua Gapoktan "Sari Tani”. Setelah diperoleh kesepakatan waktu dan masyarakat/petani sebagai target dalam pelaksanaan kegiatan pengabdian masyarakat, selanjutnya dilakukan penentuan lahan yang akan digunakan untuk demplot. Pada demplot tersebut akan dilakukan penyemprotan pupuk organik dengan menggunakan pesawat tanpa awak. Penentuan lahan dilakukan dengan memilih lahan yang ditanami padi milik petani anggota Gapoktan "Sari Tani".

Tahapan berikutnya yaitu sosialisasi dan penyuluhan, yang dilakukan dengan mengadakan pertemuan antara tim pengabdian masyarakat, kepala desa dan perwakilan anggota Gapoktan "Sari Tani". Pertemuan ini dilakukan satu kali dan dalam pertemuan ini disampaikan materi yang berkaitan dengan pemanfaatan pesawat tanpa awak dalam aplikasi pupuk organik. Setelah kegiatan sosialisasi dan penyuluhan selesai, kemudian dilanjutkan dengan praktik penyemprotan pupuk organik dengan menggunakan pesawat tanpa awak pada lahan yang telah ditentukan untuk demplot. Lahan tanaman padi yang disemprot pupuk organik dengan menggunakan pesawat tanpa awak sebanyak 10 ha.

Tahapan selanjutnya yaitu monitoring dan evaluasi (monev) yang dilakukan melalui pemantauan pertumbuhan tanaman padi yang telah disemprot pupuk organic cair dengan menggunakan pesawat tanpa awak sampai panen.

\section{HASIL DAN PEMBAHASAN}

Petani anggota Gapoktan "Sari Tani" Desa Gentan, Kecamatan Bendosari, Kabupaten Sukoharjo sudah biasa mengaplikasikan pupuk organik. Petani mengaplikasikan pupuk organik cair dengan menggunakan sprayer sehingga memerlukan waktu, tenaga, dan biaya yang relatif besar. Tanggapan petani berkaitan dengan adanya kegiatan pengabdian masyarakat ini sangat baik. Petani sangat antusias mengikuti semua tahapan kegiatan yang dilakukan dalam pengabdian masyarakat ini dan bersedia menyediakan lahan untuk praktik penyemprotan pupuk organik sebanyak 10 ha. Setelah mengikuti sosialisasi dan penyuluhan serta praktik penyemprotan pupuk organik dengan menggunakan pesawat tanpa awak, beberapa petani juga antusias untuk melakukan penyemprotan pupuk organik dengan pesawat tanpa awak pada lahan lain yang dimiliki. Petani yang mengikuti kegiatan ini sangat berminat untuk mengaplikasikan pupuk organik dengan pesawat tanpa awak karena tidak membutuhkan waktu yang lama dalam pengaplikasiannya.

Hasil pelaksanaan kegiatan pengabdian masyarakat ini dapat diuraikan sebagai berikut: 


\section{Koordinasi dan Penentuan Lahan}

Kegiatan pengabdian masyarakat di Gapoktan "Sari Tani” Desa Gentan, Kecamatan Bendosari, Kabupaten Sukoharjo dimulai dengan koordinasi bersama ketua Gapoktan "Sari Tani" berkaitan dengan pelaksanaan program pengabdian masyarakat. Pertemuan tersebut dilakukan untuk menjelaskan dan memaparkan rangkaian kegiatan yang akan dilaksanakan oleh tim pengabdian masyarakat. (Gambar 1).

Hasil koordinasi disepakati bahwa sosialisasi revolusi industri 4.0 dengan aplikasi pupuk organik dilakukan pada Gabungan Kelompok Tani "Sari Tani” pada hari Sabtu, 4 Juli 2020. Lahan yang digunakan sebagai demplot atau percontohan penyemprotan pupuk organik menggunakan pesawat tanpa awak disepakati sebanyak 10 ha. Lahan tersebut
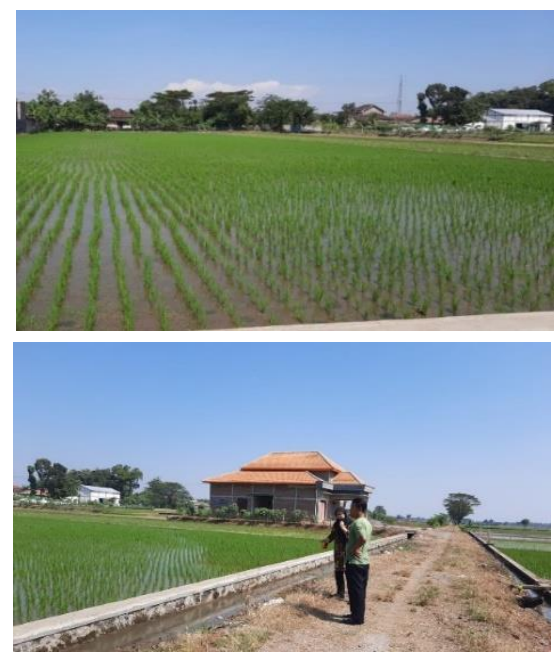

merupakan milik petani perwakilan dari 4 kelompok tani yang tergabung dalam Gapoktan "Sari Tani" (Gambar 2).

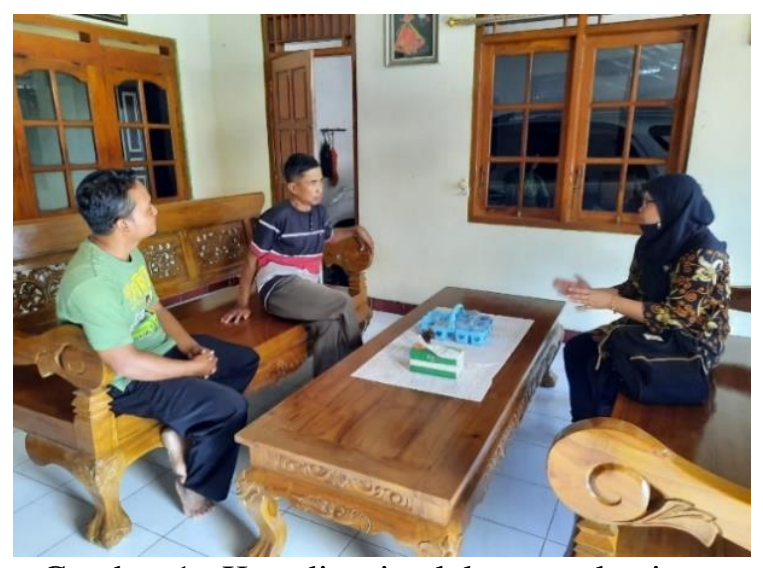

Gambar 1. Koordinasi pelaksanaan kegiatan pengabdian Masyarakat

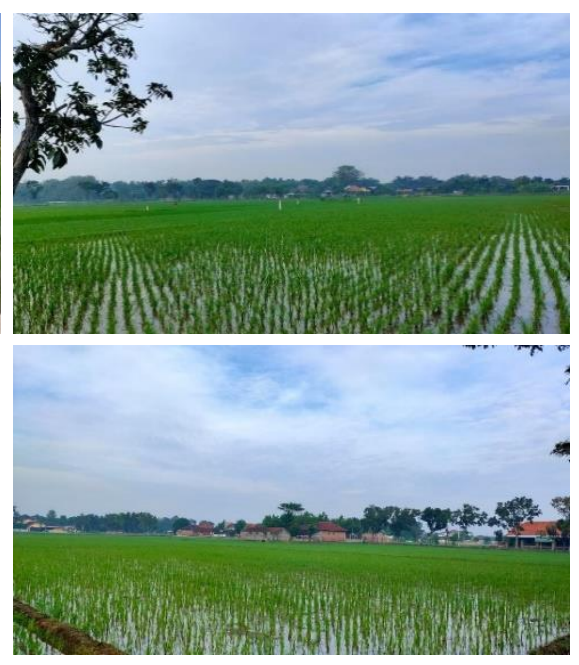

Gambar 2. Penentuan lahan untuk praktik penyemprotan pupuk organik menggunakan pesawat tanpa awak

\section{Sosialisasi dan Penyuluhan}

Tahap selanjutnya yaitu sosialisasi revolusi industri 4.0 dalam aplikasi pupuk organik dengan menggunakan pesawat tanpa awak melalui kegiatan penyuluhan. Pelaksanaan penyuluhan hari Sabtu, 4 Juli 2020 di rumah Bapak Joko Mursito sebagai ketua Gapoktan dengan metode deskripsi atau pemaparan materi. Peserta yang hadir merupakan wakil dari 4 kelompok tani yang tergabung dalam Gapoktan tersebut, meliputi Kelompok Tani Sumber Wini, Sumber Agung, Trampil Kasil, dan Siti Aji (Gambar 3).

Materi yang disampaikan dalam sosialisasi dan penyuluhan ini adalah mengenai perkembangan teknologi, serta pentingnya revolusi industri 4.0 dalam bidang pertanian, khususnya berkaitan dengan pemanfaatan pesawat tanpa awak dalam aplikasi pupuk organik. Kehadiran revolusi industri 4.0 merupakan tahap revolusi teknologi dengan mengubah cara manusia beraktivitas dalam skala, ruang lingkup, kompleksitas, dan transformasi dari pengalaman hidup sebelumnya (Ghufron, 2018).

Selain itu, dalam kegiatan sosialisasi dan penyuluhan, juga disampaikan materi yang berkaitan dengan pentingnya penggunaan pupuk organik dalam budidaya tanaman. Pupuk organik merupakan pupuk yang berbahan dasar sebagian besar ataupun seluruhnya dari bahan organik yang bersumber dari sisa-sisa tanaman dan ataupun hewan. Pupuk organik dapat menyediakan bahan organik untuk 
meningkatkan hasil dan pertumbuhan tanaman dan juga memperbaiki karakteristik tanah baik fisik, kimia, maupun biologi (Multazam et al., 2014). Secara umum, pertumbuhan dan hasil tanaman dapat ditingkatkan melalui aplikasi pupuk organic. Selain itu pupuk organik juga dapat memperbaiki karakteristik dan sifat tanah, serta meningkatkan efisiensi serapan unsur hara oleh tanaman (Hidayat et al., 2015). Menurut Lee (2010), aplikasi pupuk organik memiliki efek positif yaitu dapat meningkatkan populasi mikroba dalam tanah. Pupuk organik memiliki kandungan bahan penting yang diperlukan untuk memperbaiki kesuburan tanah dan bersifat ramah lingkungan (Puspadewi et al., 2016). Dalam jangka waktu panjnag, aplikasi pupuk organik dapat meningkatkan produktivitas lahan dan mencegah degradasi lahan. Selain itu, aplikasi pupuk organik dapat menekan atau meminimalkan penggunaan pupuk anorganik (Parman, 2007). Salah satu pupuk organik yang banyak dipakai adalah pupuk organik cair karena

memiliki beberapa manfaat, antara lain merangsang pertumbuhan dan kualitas kinerja akar serta meningkatkan pertumbuhan tanaman secara keseluruhan (Hamzah, 2014). Beberapa pupuk organik cair tertentu juga memakai bakteri Azetobacter sp., Azospirilium sp, Lactobacillus sp,. Pseudomonas sp, dan Rhizobium sp. (Sipayung et al., 2017). Selain itu, beberapa pupuk organik cair juga kadang memiliki kandungan asam amino dan hormon pengatur tumbuh seperti IAA, Sitokinin dan Giberelin (Nanda et al., 2016). Penggunaan pestisida dan herbisida kimia sintetik di kalangan petani khususnya petani anggota Gapoktan "Sari Tani" Desa Gentan sudah menjadi kebiasaan dalam pengendalian organisme pengganggu tanaman di sawah. Hal ini berdampak pada terjadinya pencemaran lingkungan dan hasil panen, resistensi gulma, dan hilangnya musuh alami (Budi \& Hajoeningtijas, 2013).
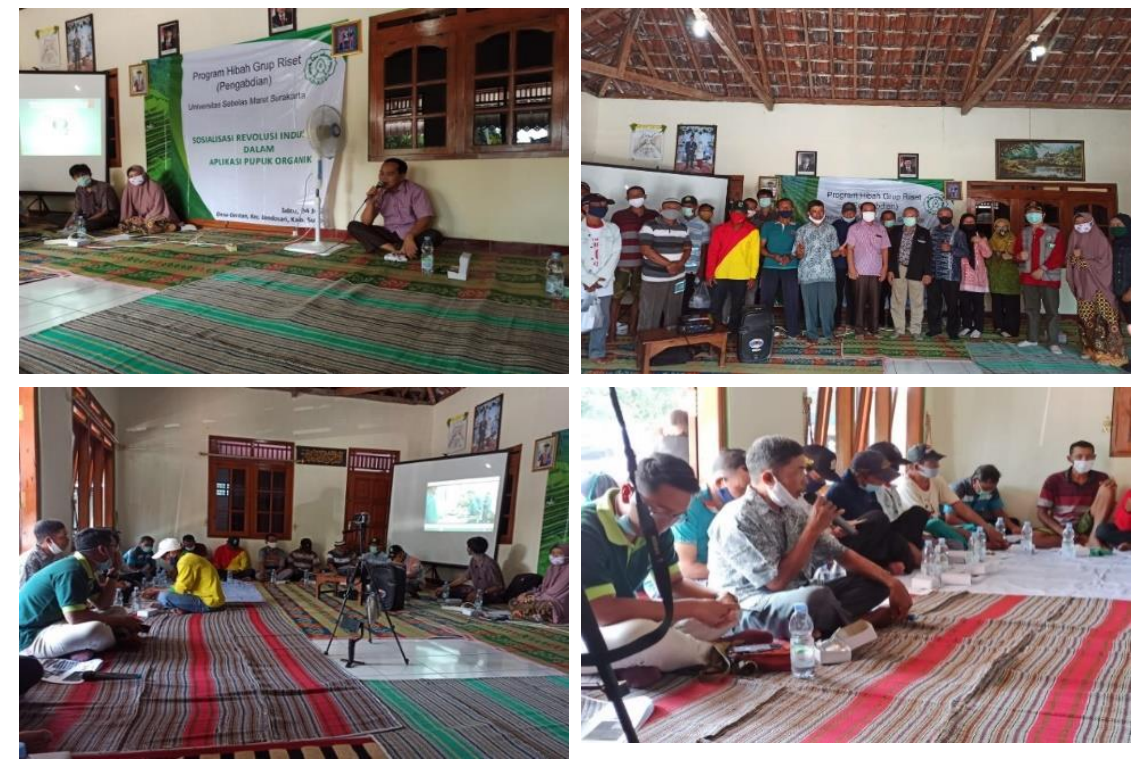

Gambar 3. Kegiatan penyuluhan dan sosialisasi pada Gapoktan "Sari Tani"

Kegiatan pengabdian masyarakat ini dapat mengedukasi dan memberikan wawasan langsung kepada petani. Hal ini dapat dilihat pada antusiasme dan banyaknya masyarakat yang bertanya mengenai pesawat tanpa awak dan penggunaanya untuk penyemprotan pupuk organik. Penerapan revolusi industri 4.0 berpeluang besar untuk meningkatkan global income, mengurangi biaya untuk transportasi dan komunikasi, menciptakan hasil atau produk dan pasar baru, meningkatkan kualitas hidup, tempat kerja lebih aman dan meningkatkan layanan kesehatan. Teknologi yang mengintegrasikan dunia fisik, digital, dan biologi secara fundamental akan mengubah pola hidup dan interaksi manusia (Tjandrawinata, 2016).

Praktik penyemprotan pupuk organik dengan menggunakan pesawat tanpa awak (drone)

Tahap selanjutnya dalam kegiatan pengabdian masyarakat ini adalah praktik penyemprotan pupuk organik dengan menggunakan drone yang dilakukan pada lahan seluas 10 ha yang sudah ditentukan sebelumnya. 
Lahan yang digunakan untuk demplot tersebut adalah lahan milik anggota Gapoktan "Sari Tani". Penggunaan pesawat tanpa awak dalam aplikasi penyemprotan pupuk organik diharapkan dapat mendukung pembangunan sektor pertanian melalui peningkatan produktivitas dan efesiensi usaha tani. Selain itu, penggunaan teknologi sebagai konsep digitalization of production dalam bidang pertanian diharapkan dapat menarik minat anak muda dalam menggeluti bidang pertanian (Puspitasari, 2019).

Praktik penyemprotan pupuk organik dengan menggunakan pesawat tanpa awak dilaksanakan langsung setelah kegiatan penyuluhan selesai. Peserta penyuluhan mengikuti kegiatan di lahan percontohan yang telah ditentukan untuk mengikuti praktik (Gambar 4.)


Gambar 4. Praktik penyemprotan pupuk organik dengan drone

Drone merupakan pesawat tanpa awak yang dikendalikan jarak jauh. Berdasarkan jenisnya, ada dua yaitu fixed wing (mempunyai bentuk seperti pesawat terbang yang dilengkapi sistem sayap) dan multicopter (untuk terbang menggunakan putaran baling-baling) (Suroso, 2016).

Pesawat tanpa awak yang digunakan dalam praktik penyemprotan pupuk organik ini merupakan pesawat tanpa awak dengan kapasitas 10 liter dengan empat nozzle. Pesawat tanpa awak tersebut dapat diaplikasikan pada ketinggian 4-5 m yang mampu menyemprot pupuk organik 30-40 liter untuk 1 ha lahan dalam kurun waktu 10-15 menit dengan 4 kali terbang per hektar. Penggunaan drone membutuhkan waktu lebih singkat dibandingkan penyemprotan secara konvensional yang membutuhkan waktu 20 jam.ha $^{-1}$ (Khoirunisa \& Kurniawati, 2019). Yudhana \& Wardani (2017) menyatakan bahwa penyemprotan menggunakan pesawat tanpa awak atau quadcoper membutuhkan waktu 12,5 jam.ha ${ }^{-1}$ sedangkan secara konvensional memerlukan waktu sekitar 20 jam.ha $^{-1}$

Penyemprotan pupuk organik dengan menggunakan pesawat tanpa awak dapat memberikan manfaat khususnya dalam efisiensi waktu dan meminimalkan dampak negatif terhadap kesehatan para petani (Khoirunisa \& Kurniawati, 2019). Penggunaan pesawat tanpa awak yang dikendalikan oleh remote control merupakan langkah yang efektif dan efisien (Kilmanun \& Astuti, 2020).

\section{Monitoring dan Evaluasi}

Monitoring dan evaluasi dilakukan untuk mengetahui perkembangan tanaman padi yang disemprot pupuk organik dengan menggunakan pesawat tanpa awak serta mengetahui tanggapan masyarakat terhadap teknologi yang diperkenalkan pada petani. Melalui kegiatan pengabdian ini, petani mendapatkan wawasan dan pandangan lebih baik dalam pemanfaatan teknologi oleh para petani. Implementasi 
revolusi industri 4.0 ini mendorong petani untuk dapat melakukan proses usahatani yang lebih baik dan efisien, sehingga tercapai efisiensi, peningkatan produktivitas padi, dan peningkatan daya saing.
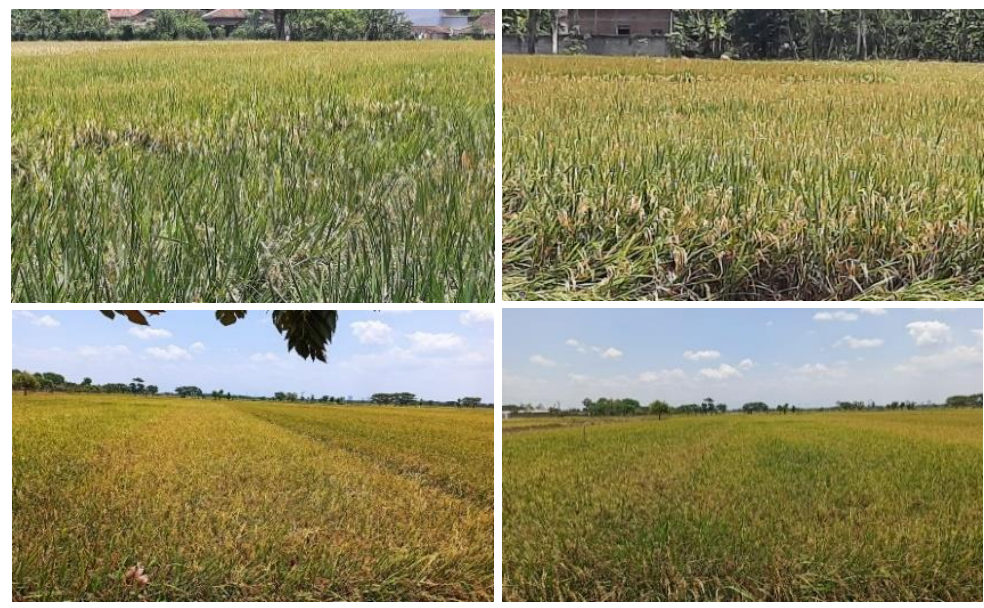

Gambar 5. Monitoring tanaman padi yang sudah disemprot pupuk organik dengan menggunakan pesawat tanpa awak

\section{KESIMPULAN}

Kegiatan pengabdian masyarakat ini dimaksudkan untuk sosialisasi dan pengenalan teknologi yang dapat dimanfaatkan untuk mendukung kegiatan pertanian agar lebih efisien yaitu melalui sosialisasi dan penyuluhan, praktik penggunaan pesawat tanpa awak untuk penyemprotan pupuk organik pada padi, monitoring dan evaluasi. Tanggapan petani yang mengikuti kegiatan ini sangat bagus. Hal ini terlihat dari tingkat partisipasi petani anggota Gapoktan "Sari Tani" yang tinggi dalam mengikuti semua tahapan kegiatan mulai dari sosialisasi dan penyuluhan, praktik aplikasi pupuk organik menggunakan pesawat tanpa awak serta monitoring dan evalausi. Melalui kegiatan pengabdian masyarakat ini diharapkan memberikan kontribusi dalam diseminasi teknologi pertanian kepada petani. Para petani mendapatkan wawasan tentang revolusi industri 4.0 dalam aplikasi pupuk organik dengan menggunakan pesawat tanpa awak. Para petani yang telah paham diharapkan dapat mengaplikasikan penyemprotan pupuk organik dengan menggunakan pesawat tanpa awak secara bersama-sama.

\section{UCAPAN TERIMA KASIH}

Tim Pengabdian Masyarakat menyampaikan banyak terima kasih kepada Lembaga Penelitian dan Pengabdian Masyarakat Universitas Sebelas Maret Surakarta atas pendanaan PNBP tahun anggaran 2020 yang sudah diberikan sehingga kegiatan pengabdian masyarakat ini dapat berjalan lancar. Tim Pengabdian Masyarakat juga mengucapkan terima kasih kepada Kepala Desa dan Gabungan Kelompok Tani "Sari Tani" Desa Gentan, Kecamatan Bendosari, Kabupaten Sukoharjo atas dukungan dan partisipasinya dalam kegiatan pengabdian ini.

\section{DAFTAR PUSTAKA}

Budi, G. P., \& Hajoeningtijas, O. D. (2013). Penerapan herbisida organik ekstrak alangalang untuk mengendalikan gulma pada mentimun. Agritech, 15(1), 32-38.

Fatchiya, A., Amanah, S., \& Kusumastuti, Y. I. (2016). Penerapan inovasi teknologi pertanian dan hubungannya dengan ketahanan pangan rumah tangga petani. Jurnal Penyuluhan, 12(2), 190-197. http://ejurnal.litbang.pertanian.go.id/index .php/fae/article/view/4280

Ghufron, G. (2018). Revolusi industri 4.0: tantangan, peluang, dan solusi bagi dunia pendidikan. Seminar Nasional Dan Diskusi Panel Multidisiplin Hasil Penelitian Dan Pengabdian Kepada Masyarakat 2018, 1(1), 332-337.

Hamzah, S. (2014). Pupuk organik cair dan pupuk kandang ayam berpengaruh kepada pertumbuhan dan produksi kedelai (Glycine max L). Jurnal Ilmu Pertanian" Agrium", 18(3), 228-234. 
Hernanda, E. N. P., Indriani, Y., \& Kalsum, U. (2017). Pendapatan dan ketahanan pangan rumah tangga petani padi di desa rawan pangan. Jurnal Ilmu-Ilmu Agribisnis, 5(3), 283-291.

Hidayat, A. M., Ambarwati, E., Wedhastri, S., \& Basunanda, P. (2015). Pengujian lima pupuk organik cair komersial dan pupuk NPK pada Jagung (Zea mays L.). Jurnal Vegetalika, 4(4), 9-20.

Khoirunisa, H., \& Kurniawati, F. (2019). Penggunaan Drone dalam Mengaplikasikan Pestisida di Daerah Sungai Besar , Malaysia. Jurnal Pusat Informasi Masyarakat, 1(1), 87-91.

Kilmanun, J. C., \& Astuti, D. W. (2020). Potensi dan kendala revolusi industri 4.0. di sektor pertanian. Prosiding Seminar Nasional Kesiapan Sumber Daya Pertanian Dan Inovasi Spesifik Lokasi Memasuki Era Industri 4.0, 35-40.

Lee, J. (2010). Effect of application methods of organic fertilizer on growth, soil chemical properties and microbial densities in organic bulb onion production. Scientia Horticulturae, 124(3), 299-305. https://doi.org/10.1016/j.scienta.2010.01.0 04

Multazam, M. A., Suryanto, A., \& Herlina, N. (2014). Pengaruh macam pupuk organik dan mulsa pada tanaman brokoli (Brassica oleracea L. var. Italica). Jurnal Produksi Tanaman, 2(2), 154-161.

Nanda, E., Mardiana, S., \& Pane, E. (2016). Pengaruh pemberian berbagai konsentrasi pupuk organik cair urine kambing terhadap pertumbuhan dan produksi tanaman jagung manis (Zea mays saccharata Sturt). Agrotekma, 1(1), 81-90.

Parman, S. (2007). Pengaruh pemberian pupuk organik cair terhadap pertumbuhan dan produksi kentang (Solanum tuberosum L.). Buletin Anatomi Dan Fisiologi, XV(2), 2131. https://doi.org/10.14710/baf.v15i2.2569

Puspadewi, S., Sutari, W., \& Kusumiyati, K. (2016). Pengaruh konsentrasi pupuk organik cair (POC) dan dosis pupuk N, P, $\mathrm{K}$ terhadap pertumbuhan dan hasil tanaman jagung manis (Zea mays L. var Rugosa Bonaf) kultivar talenta. Jurnal Kultivasi, 15(3), 208-216. https://doi.org/10.24198/kltv.v15i3.11764

Puspitasari, R. D. (2019). Pertanian berkelanjutan berbasis revolusi industri 4.0. Jurnal Layanan Masyarakat, 3(1), 26. https://doi.org/10.20473/jlm.v3i1.2019.2628

Sipayung, N. Y., Gusmeizal, \& Hutapea, S. (2017). Respon pertumbuhan dan produksi tanaman kedelai (Glicyne max L.) varietas tanggamus terhadap pemberian pupuk kompos limbah brassica dan pupuk hayati riyansigrow. Agrotelkma, 2(1), 1-15.

Suroso, I. (2016). Peran drone/unmanned aerial vehicle (UAV) buatan sttkd dalam dunia penerbangan. Prosiding Seminar Nasional 2016 Pengembangan Dan Kebijakan Regulasi Penerbangan Dan Antariksa: Problema Dan Tantangan, 104-112.

Tjandrawinata, R. (2016). Industri 4.0: revolusi industri abad ini dan pengaruhnya pada bidang kesehatan dan bioteknologi. Medika, 29(1), 31-39. https://doi.org/10.5281/zenodo.49404

Yudhana, A., \& Wardani, M. (2017). Rancang bangun penyemprot pestisida untuk pertanian padi berbasis quadcopter. Jurnal Ilmiah Teknik Elektro Komputer Dan Informatika, 3(2), 132-140. https://doi.org/10.26555/jiteki.v3i2.7479 